\title{
Survey on the Demand of ESP-Business English Talents of Export-Oriented Enterprises in Taian City
}

\author{
Xiujuan Wang1, Jilian $\mathrm{Hu}^{1}{ }^{*}$, Wenjing Wang2, Jie Pan ${ }^{2}$, Wen Fu${ }^{2}$ \\ ${ }^{1}$ School of Economics and Management, Shandong Agricultural University, Taian, China \\ ${ }^{2}$ College of Foreign Languages, Shandong Agricultural University, Taian, China \\ Email: xjw9007@126.com, *Jlhu@sdau.edu.cn
}

How to cite this paper: Wang, X. J., Hu, J. L., Wang, W. J., Pan, J., \& Fu, W. (2017). Survey on the Demand of ESP-Business English Talents of Export-Oriented Enterprises in Taian City. Creative Education, 8 , 574-586.

https://doi.org/10.4236/ce.2017.84045

Received: February 28, 2017

Accepted: April 22, 2017

Published: April 27, 2017

Copyright $\odot 2017$ by authors and Scientific Research Publishing Inc. This work is licensed under the Creative Commons Attribution International License (CC BY 4.0).

http://creativecommons.org/licenses/by/4.0/

\begin{abstract}
With the integration of China and WTO, the export-oriented economy in Taian city is gradually showing the booming trend. And the increase of the foreign-related enterprises also makes the increase of Business English talents. By conducting questionnaire and interview of the Export-oriented Enterprises in Taiancity, this paper analyzes the demand of Business English talents of export-oriented enterprises in Taian city. Results show that there are some differences between the demand of the enterprises and the present situation of the Business English talents. Then, this paper gives some suggestions and counter-measures for this situation.
\end{abstract}

\section{Keywords}

Export-Oriented Economy, Foreign-Related Enterprises, Business English Talents

\section{Introduction}

The ESP (English for Specific Purposes) theory emerges as the times require in 1960s. Business English is one kind of ESP which combines English with business knowledge and skill (Fairclough, 1989; Ferris, 2015). In 1980s, there are more than 800 colleges in China that started to set up the English major that relates to the business English. From 2012 to 2014, the number of universities which have the Business English major ups to 216 including 8 in Shandong province.

With the development of China's all-around and multilevel economy, the role of Business English in the economic construction and international communication becomes more and more prominent (Krashen, 2010). The expansion of ex- 
port-oriented economy also makes the demand of Business English talents reach to an unprecedented point (Hutchinson, 1997). The "Annual Report on the Development of Chinese Talents" shows that the demand of Business English talents in the future three years will be 2000 to 3000 thousands. As a big city with a large population and good location, Taian city is regarded as one of the most potential cities of Shandong province. According to the statistics, the GDP (Gross Domestic Product) of Taian city in 2014 is up to 3569.8 million yuan and increases $10.1 \%$, which ranks the second in Shandong province. Owing to its convenient transportation, Taian becomes the important logistics center and trade city of China. Meanwhile, the export-oriented economy of Taian city springs up like the mushrooms in recent years (Robinson, 2000). From 1988 to 2005, the number of the export enterprises in Taian city increased from several to more than 2000, and the contractual FDI (Foreign Direct Investment) ups to USD 22 million. And the varieties of exports are more than 1000, which find a good sale in about 120 countries (Zhang, 2015). The typical products among these exports are labor concentrated products and agricultural products, such as peanut, soybean and textile. And the overseas investment enterprises increased to 39 , which drives more than 80 projects on overseas investment. In 2010, the customs duty of Taian city grows on a large scale and hits a historical high. In January 2014, the total export-import achieves to $\$ 10$ million which includes $\$ 4.9$ millionof export volume and \$5.1 million import volume. The total volume ranks the seventh in Shandong province.

This is exactly the reason why more and more foreign-related enterprises are eager to recruit more Business English talents than before (Widdowson, 2008). And most enterprises put new and high requirement for the Business English talents. It is can be seen from some recruitment information that many enterprises splash out higher cash for the high-quality Business English talents. But the reality is that there is still a big vacancy between the demand and the supply of the Business English talents in many export-oriented enterprises in Taian city. What's more the ability of the Business English talents in negotiation, logistics, tariff, insurance and other businesses cannot meet the business requirements in the practice of the foreign trade (Yang, 2012). In this context, this paper aims to accurately analyze the present actual situation of the demand of the Business English talents, which will be helpful to the interaction of the Business English talents and the regional economic development in Taian city and facilitate the economic development. This paper consists of five parts: Part I is the introduction, Part II is Research Design, Part III is the Research Finds and Data Analysis, Part IV is Suggestions and counter-measures and part V is the conclusion of the whole paper.

\section{Research Design}

In order to know what qualities of Business English talent do the export-oriented enterprises really need and what gap between the present situation of the Business English talent qualities and the demand of the enterprises a questionnaires 
are designed.

This study mainly adopts questionnaire (20 items included) survey and interview. In order to verify the validity and reliability of the questionnaire, the actual time needed, and to clarify any confusing item, a pilot test was carried out in April, 2015. It took about 15 minutes for them to complete the questionnaire. The reliability analysis with SPSS 13.0 showed the Cronbach coefficient alpha for the questionnaire was .875 and for its three subscales were $.662, .759$ and .680 respectively. Based on the analysis of the pilot test, five items were eliminated in order to improve the internal reliability of the whole questionnaire and that of its subscales. After the modification, the Cronbach coefficient alpha of the questionnaire used in the present study was .904 and for its three subscales were $.724, .759$ and .775 respectively, the reliability of the whole questionnaire is acceptable.

\subsection{Participants}

The participants of the present study were 30 export-oriented enterprises in Taian city, 576 managers from those enterprises participated in the questionnaire. The interview participants are some main company managers, executive recruiters and governors of these enterprises. Among them, 10 were female and 20 were male. They ranged in age from 35 to 48 , with an average of 38.6.

\subsection{Design of the Research}

\subsubsection{Design of Questionnaire}

The questionnaire mainly includes two parts: part 1 is the basic information about the enterprises questioned; part 2 lists out the conditions of the demand of the English skill and the knowledge structure of the Business English talents. The range of these 10 foreign-related enterprises is very wide, which includes Tianyuan construction company, Huamei textile limited company, Jingshi ceramics limited liability company, Zhiquan artware limited company, Tailai agricultural products company, Jinluo meat product limited company, Hengtong chemical limited liability company, Huana wood limited company, Aite hardware store company and Lunan pharmaceuticals company.

\subsubsection{Design of the Interview}

The interview centers on the theme of the survey which mainly talks about the demand of the Business English talents and the differences about the qualities between the demand and the real condition which concerns the satisfaction degree of the enterprises to Business English talents. The interview uses the way of random selection, which means three companies are chosen at random. These three companies are Tianyuan Construction Company, Zhiquan art-ware limited company and Jinluo meat product limited company. They are very famous in Taian city. With a long history, their products find a good sale in all over the world. The interviewees are the executive recruiters and company managers in each enterprise. Each interview lasts about 30 minutes, and there are 3 inter- 
viewees in each company.

\section{Research Finds and Data Analysis}

As is shown in Table 1, 600 questionnaires are given out and 576 are taken back, so the recovery is $96 \%$. There are 552 left after thesifting, which means the effective rate is $92 \%$. Among these enterprises surveyed $72 \%$ are processing and manufacture industry and the left $28 \%$ are agricultural production. This is also the present situation of Taian city which the labor concentrated industry is the main part of its economy. And this kind of enterprise also occupies a big proportion of the foreign-related enterprises in Taian city. From the characteristic of the enterprise, it can be seen that $82 \%$ of these enterprises are private enterprises and $8 \%$ of these are overseas-funded enterprises. The annual number of the Business English talents that every enterprise need is 5 (80\%). According to the total number of the export-oriented enterprise in Taian city, the demand of the Business English talents in Taian city in the future is large. From the questionnaire we can easily see that the Business English talents that are most urgent needed are the export traders (74\%), such as the merchandisers, sales executives and the customs declarers. Another kind of talents is the interpreters and the translator, which takes up $21 \%$.

It can be seen from the questionnaire (Table 2) that the requirement of the education background of the Business English talents that most enterprises ask for is the bachelor degree which accounts for $67 \%$. Just $7 \%$ enterprises ask the Business English talents to have the graduate degree, meanwhile $17 \%$ enterprises show that the college degree talents for the job is enough. Even $9 \%$ enterprises have no requirement for the education background. Combined with the interview, it shows that most enterprises pay more attention to the practical ability of the Business English talent rather than the education background. And some interviewees say that from the perspective of cost-saving, most enterprises prefer college degree Business English talents as long as they can meet the need of real business. So if the graduate and bachelor degree talents who just have a good education background but do not have the special skills, they still cannot win the recognition from the enterprises.

Most enterprises have their own requirement for the English certificates which can prove the English ability of the English talents in some degree. Among these certificates, the certificate of the College English Test Band 4 is the

Table 1. General introduction of the enterprise interviewed.

\begin{tabular}{ccccc}
\hline Character & $\begin{array}{c}\text { Private } \\
\text { enterprise (82\%) }\end{array}$ & $\begin{array}{c}\text { Overseas-funded } \\
\text { enterprise (8\%) }\end{array}$ & $\begin{array}{c}\text { State-owned } \\
\text { enterprise (7\%) }\end{array}$ & $\begin{array}{c}\text { Individual } \\
\text { enterprise (3\%) }\end{array}$ \\
\hline $\begin{array}{c}\text { Scale } \\
\text { Demand/year }\end{array}$ & $500-1000$ & $1000-2000$ & $>2000$ & $100-200$ \\
Position & Secretary & interpreter & Export trader & $\begin{array}{c}\text { Foreign trade } \\
\text { merchandiser }\end{array}$ \\
\hline
\end{tabular}


Table 2. The demand of the enterprise and their proportion.

\begin{tabular}{|c|c|c|c|c|c|}
\hline The & \multicolumn{5}{|c|}{ The type and proportion } \\
\hline $\begin{array}{l}\text { Education } \\
\text { background }\end{array}$ & $\begin{array}{c}\text { College } \\
\text { degree }(17 \%)\end{array}$ & $\begin{array}{c}\text { Bachelor } \\
\text { degree }(67 \%)\end{array}$ & $\begin{array}{c}\text { Graduate } \\
\text { degree (7\%) }\end{array}$ & $\begin{array}{l}\text { Unlimited } \\
(9 \%)\end{array}$ & \\
\hline Major & $\begin{array}{c}\text { Business } \\
\text { English (47\%) }\end{array}$ & $\begin{array}{l}\text { International } \\
\text { trade }(33 \%)\end{array}$ & $\begin{array}{c}\text { E-commerce } \\
(11 \%)\end{array}$ & English $(6 \%)$ & Unlimited (3\%) \\
\hline Certificate & CET-4 (47\%) & CET-6 (11\%) & TEM-4 & BEC (39\%) & Unlimited (4\%) \\
\hline Speaking & \multicolumn{5}{|c|}{ To accomplish the basic foreign communication ( $80 \%)$} \\
\hline Listening & \multicolumn{5}{|c|}{ The things related to the business ( $49 \%)$} \\
\hline Interpreting & \multicolumn{5}{|c|}{ To deal with the problems of the process of the communication neatly (98\%) } \\
\hline Writing & \multicolumn{5}{|c|}{ To write the business letters (51\%) } \\
\hline Reading & \multicolumn{5}{|c|}{ To read the materials needed by the work ( $55 \%$ ) } \\
\hline
\end{tabular}

basic one, which makes up the $47 \%$. And $11 \%$ enterprises ask the talents to pass the College English Band 6. The reason for this phenomenon is that the CET4 (College English Band 4) and CET6 (College English Band 6) have a deep influence and they are accepted by more and more enterprises. So most enterprises take them as the standard to judge the English ability of the talents. In addition, the certificates of the English for specific purposes, just like BEC (Business English Certificate) which are accepted in the overseas-funded enterprises before attracting more attention of the enterprises. What's more, the certificates of TEM-4 or TEM-8 (Test for English Majors-4 or -8) which are the special certificate for English majors do not get high recognition in these foreign-related enterprises.

What the enterprises really focus on are the English skills of the Business English talents. The character of the enterprises decides that they have to communicate with the foreign customers, so the speaking skill is not only necessary but also crucial. 80\% enterprise asks the Business English talents to have the ability of accomplishing the basic foreign communication. For example, the talents need to acquire the oral communication skills of business discussion, conducting a meeting, product presentation, signing a contract and other parts of the foreign trade business. Another important English skill the enterprises think highly of is the skills of interpretation and translation. Through the questionnaire and the interview, we can know that $98 \%$ enterprises need the interpreting skill and they need the students to have the ability to deal with the problems of the process of the communication neatly. For writing, it focuses on the ability of the writing of the business letters (51\%), which can guarantee the progress of the business. And the writing of the business reports and bidding documents is also essential. Listening actually is the basis of communication, only when one can understand what other says can he answer the question and do the conversation. So there are $49 \%$ enterprises asking the talents to understand the things related to the business. For reading, 55\% enterprises say that the talents just need to have the ability to read the materials needed by the work. By comprehensive 
analysis, what the enterprises regard important are the speaking and interpreting skills. They need the talents to have a communication with higher quality.

It is no doubt that the inter-disciplinary talents are the favorite in all walks of life. For the major of the talents, $47 \%$ enterprises ask for the Business English majors and $33 \%$ enterprises ask for the international trade majors. It can be easily seen that the market is developing and the need is changing. So the all-round developed people will go with the demand of the times.

According to the interview, generally the satisfaction degree of the enterprises to the Business English talents is not high. And there are still some differences between the demand and the present situation. The interviewees say that the enterprises satisfy the skill of reading and writing, which take up the $80 \%$ and $71 \%$. But for other skills, it is agreed that they still remain to improve. This also corresponds to the findings of the questionnaires.

Most enterprises are pleased with the abilities of the application of knowledge, post adaptability, self-directed learning and others. But $10 \%$ interviewees express that the ability of the practical innovation is not satisfied. However innovation is the demand of the time. The interviewees say that innovation means the new idea and new opportunity. For a company, opportunity is the success. And there are still 3\% interviewees think that the ability of the operation of computer is not to a satisfactory level. Although the popularizing rate of computer is high, most people take it as an entertainment tool. And the use of computer for work is just restricted to the operation of the office software. So it needs more skills for the talents to handle various problems.

\section{Suggestions and Counter-Measures}

The cultivation of the Business English talents should be established in at the service of the development of the social economy, especially the demand of the development of the regional economy. So the cultivation of the Business English talents should pay more attention to the requirement of the development of the regional economy. Only giving way to a more social economy-oriented mode can the talents meet the need of the development of the regional economy.

\subsection{From the Perspective of the Government}

\subsubsection{Reinforecing the Financial and Policy Support}

The policy promulgated by the government often can show the direction to the society. The government of Taian city should publish more preferential policy to promote the cultivation of the Business English talents. The government should confirm the new professional training goals for cultivating the high-competent and technical talents. The graduates of Business English major go in for the overseas-funded enterprises or foreign trade enterprises and work as the export traders or interpreters. So the professional training goal should be positioned on cultivating the specific and creative Business English talents who have the good professional ethics and know the basic knowledge of the field of international economy and trade well, in the same time he need to have the strong English 
skills and experienced practical ability. More investment should be put in the cultivation of the Business English talents. The government can fund some special scholarship to encourage the students to take part in some commercial practice activities or competitions organized by the government.

\subsubsection{Promoting the Reform of the Curriculum System of the Business English Major}

From the survey we can see that what the enterprises need is the inter-disciplinary talents. The cultivation of the inter-disciplinary talents is put forward at the end of the 20th century and accepted by the market now. And it is also the direction of the reform in the future (Dai Weidong 2007). And the key point of the reform of the course system is the change of the course provision and content. The first one also the most important one is to highlight the cultivation of the application ability. Through the teaching system which is the integration of theory and practice to foster the eligible high-competent and technical talents. In the second place, the government should carry out diverse technical training and social work and then promote the ability of development of the industry of professional services.

\subsection{From the Perspective of the Universities}

\subsubsection{The Reform of the Teaching Concept and Method}

The renewal of the teaching idea needs to treat the teaching practice with the eye of development. It requires the integration of the foreign advanced teaching idea with the regional reality and the specific characteristics of the students. Because of the characteristic of the traditional language teaching, the reform of the teaching method asks for the change of the class placement. Various classroom teaching modes are needed to provide more practical opportunities for students. The more practical training are putted the more effective results will be gained. What's more, the colleges and universities should put the quality-oriented education in the first place all through the four years, and put it into effect in every teaching link of basic teaching, professional teaching and practical teaching.

\subsubsection{Enhancing the Construction of the Teaching Group}

Most Business English teachers in colleges and universities are lack of the experience of working in the enterprises, which means they just acquire the theoretical knowledge without the operation skills. On the one hand, teachers need to improve themselves through the study of the theoretical knowledge and the practice in the real business. On the hand, college or the university should regularly invite famous experts or entrepreneurs who work in the enterprises to give lectures to the students.

\subsubsection{Introducing the Texts for the Vocational Certificates}

The aim of introducing of the text for the vocational certificate is to cultivate the precise top-level talent. The emphasis of this export-oriented enterprise when they have a recruiting except the academic certificate is the vocational certificate. If the applicants have some certificates that relates to the position, they will be 
easier to be successful. It can be a helpful way to introduce the texts for vocational certificates in the cultivation of the Business English talents. The mode of the personnel training should be changed into a new one that with the goal of the strong ability combined with English language, cross-cultural communication and business practice. Some colleges are taking a chance of this theory. For example, in order to strengthen the competitiveness of the students, Xi'an International Studies University introduces five courses of the fundamental stage of CIMA (The Chartered Institute of Management Accountants) based on the Business English major. As it turns out that this try is useful, which the employment rate of these graduates ups to $100 \%$. This also proves that the introduction of the texts for vocational certificates is right and critical.

The introduction of these texts should also be rigorous and cogitative. The first thing need to be realized is the scientific, authority and specialty of the texts and certificates. Then BEC (Business English Certificate), TOEIC (Test of English for International Communication) and BULATS (Business Language Testing Service) are the three main Business English certificates accepted by the enterprises in China now. Among these three certificates, BEC (Business English Certificate) is the pioneer which has a great influence on the students in well-known universities. The recognition degree of BEC in enterprises is very high and is called the successful pass to the export-oriented enterprises. Not only in China, is BEC also accepted by most other countries. So if the talents want to go abroad for future study it is necessary for them to have the BEC. Compared with BEC, TOEIC and BULATS have short histories and low recognition degree in China. And the business knowledge involved by the latter two is not broad enough.

By comprehensive comparison, it shows that the text of BEC (Business English Certificate) is the most suitable one that can be introduce to the course system of Business English. According to the survey of the demand of Business English talents of the enterprises, the listening and speaking skill should be set priority among priorities in the teaching and text. And pay more attention to foster the ability of cross-cultural communication and Business practice.

\subsection{From the Perspective of Enterprises}

\subsubsection{Strengthening the Cooperation with Universities and Colleges}

The development of the regional economy makes the change of the demand of Business English talents. And only when the goal of cultivation is consistent with the demand of the region, can the colleges foster more qualified talents for the enterprises. With this not only the employment rate of these Business English graduates can improve, but also the development of the regional economy can get more power. So the enterprises are supposed to strengthen the cooperation with universities and colleges. The enterprises ought to regularly organize the seminars with the colleges to discuss the differences between the demand and the present situation of the Business English talents, which will show a right direction for the cultivation of Business English talents in colleges. The enterprises 
can also try the ordering-list type training with the colleges and universities. At the same time, relying on enterprises, the implementation of "order type" education makes the students more practical and targeted, which will be more popular with the employers. So college-enterprise cooperation is one of the most important ways of running higher vocational school and "order-type" cultivation mode can directly help graduates find jobs easily. With the cultivating plan made by the enterprise and college together, both sides can participate in the process of cultivation by taking the advantage of them, which may be in favors of the realization of the predetermined objective. But according to the research, this mode is not so popular among the enterprises and colleges, for the implementation of the "order-type" cultivation has a high requirement to the enterprises. For instance, it needs the enterprise to gain regular "bulk requirement" for the Business English talents, which means the enterprise needs to be a very large one. Then it also asks the enterprise to have a good foresee ability to the need of the market. For all these factors, only the enterprise and the college are both well-going, can they avoid risks and achieve the target of win-win.

\subsubsection{Providing the Practical Training Base}

Practice makes perfect. Just listening to what the teachers say in class is not enough for the cultivation of the Business English talents. The enterprise is the best class and the business is the best teaching material. Through experiencing the real work environment and witnessing the real trade work, students can find the shortages that they are lack of. So they will improve themselves through the practice. The enterprises can also try to let the students do some easy work to test their practical ability. From another aspect, through building the specific relationship with the specific college, the enterprise should provide more opportunities of internship to the students before their graduation. This can help the students know the interior structure and operation mode well, which will provide more position knowledge to the students. On the other hand, through the internship the enterprise can also know the students well, which can shorten the adaptive phase of the new employee and is helpful to the personnel recruitment.

\subsection{From the Perspective of the Students}

\subsubsection{The Study of the Professional Knowledge}

Every occupation has its own profession and every position has its specialization. Business English is a kind of English for specific purpose. There is no denying that there is a lot of professional knowledge for the Business English talents to acquire. If the students want to work in the export-oriented enterprises, the first thing they need to do is to know more professional knowledge and skills as well. Business English not only consists the knowledge of English but also business. And the latter even takes up a large percent. The students should know business skills, such as the skill of the writing of business letter, business interpretation and export sales. So the students need to grasp the basic knowledge of both English and business as much as possible. And the students also need to learn to integrate the two courses together which will have a better effect. 


\subsubsection{The Improvement of the Comprehensive Abilities}

The demand of the inter-disciplinary talents is the trend of most enterprises in the future. Enterprise is the specific organization with a basic goal of making profit. Each enterprise wants to save the cost by all the ways. So on the one hand, the inter-disciplinary talents can save lots of costs for the enterprise in some degree. On the another hand, the inter-disciplinary talent means the one who has high ability, so these people can be more capable to the demand of the work. No denying that compared with the professional talents, the inter-disciplinary talents can easily go with the stream. Comprehensive abilities not only include the ability of different majors but also the ability of practical operation and flexibility. For example, when the enterprises have business with a foreign country, they usually need an interpreter, a foreign trade specialist and others. But if there is a person who can integrates all these abilities, the enterprise will be willing to put the staff in an important position. There still other necessary abilities that the talents need to acquire, for example, the operation of the computer. The development of Internet provides an important and effective chance for the foreign trade, for more and more trades are done by the Internet. Internet has become an e-commerce platform. Because of the demand of the trend of e-commerce, the ability of the operation of computer becomes more and more necessary. And another ability deserves to be mentioned is innovation. A creative talent means new blood and new energy for the enterprise. Especially in this world that changes with each passing day, if the enterprises want to catch up with the need of the time, they need to have the new idea and new creation every day to provide themselves more opportunities to survive under the drastic competition. So the students should learn to be good at observation and discovery. They need to know the main stream of the time and the trend of the change, and then give the suggestion and strategy to the change according to the need.

\subsubsection{The Promotion of the Self-Cultivation}

Self-cultivation is the inner personnel quality and it is an essential part for the success of a person. Nowadays, there is a same requirement in the recruitment information of most enterprises. The requirement is written like that "the person with both political integrity and professional competence", and the political integrity is often put in the first place. The deficiency of one kind of ability often can be offset by another one, but the hiatus of the personnel quality is often fatal. There is no enterprise that will put the development of their future into the hand of a person without a good moral quality, even he who has a high professional competence. So the students need to pay high attention to the promotion of the self-cultivation. A good self-cultivation can be reflected in many aspects. And there are some main points, such as honesty, diligence, caution and modesty. Honesty means that the words and deeds both can be trusted. And this is also the basis for one to get along well other people. In an enterprise, being honest in an enterprise not only asks one to be responsible to the fault or wrong but also to keep the commercial secret. Diligence is the attitude to work and life. It is said that diligence is the means by which one makes up for one's dullness. So god will 
help the man who helps himself. Finally one will be successful as long as he is diligent. And no matter in what position, diligence is an important way for one to overcome difficulties and meet with success. Then caution is a special aspect of one's personnel quality which has a close relation with one's character. Caution asks one to keep his eyes open to the hair like things in the life. And this kind of person can often have an insight into the changes in life and make few mistakes in work. So most enterprises are in fond of that kind of person. The next one is modesty which means having no arrogance. The modest person often treats people and things with an open mind. Maybe they have their own opinion, but they are willing to listen to others' views. With this quality this kind of person often has a good interpersonal relationship with others. So many people would like to help him when he is in need and even to submit to him in working.

\section{Conclusion}

Nowadays, the development of the Business English major in China is presenting a good momentum, but the traditional and simplex training mode is out of line with the employment of students and the demand of market. With the maturity of the environment of international economy and investment, the society has its new demand for the Business English talents. The development of the foreign trade in Taian city has a big market and potential. Because of the particularity of the regional economy, the export-oriented enterprises in Taian city also have their own special needs for the Business English talents according to their development. So the cultivation of the inter-disciplinary Business English talents needs to serve for the development of the regional economy. All of these ask for the reform of the cultivation of the Business English talents. And the reform of the training of the Business English talents needs the effort of the society, the universities, the enterprises and the students themselves. In the first place, the government should try their best to provide a helpful social environment for this reform. The government should reinforce the financial and policy support to the cultivation of the Business English talents. Then they also need to promote the reform of the curriculum system of the Business English major. The influence of the government is often strong. With the requirement more and more universities and colleges will answer the call and do follow the advocacy. So the action of the government is the basic guarantee for others. Secondly, colleges and universities also have a lot of things to do. As we all know, the teaching concept and method in most colleges and universities are traditional and obsolete, which leads to the inefficiency of the cultivation of the talents. So promoting the reform of the curriculum system of the Business English major is the first thing the colleges need to do. Just with this is not enough, the colleges ought to enhance the construction of the teaching group. Teacher is the basic person to give the knowledge and information to the students. So the quality of the teaching group has an important impact on the quality of the cultivation of the talents. And another thing the colleges and the universities can have a try is to introduce the texts for the vocational certificates. Some certificates are the necessi- 
ties for the Business English students who want to have a job in the exportoriented enterprises. So the introduction of the text of the vocational certificates can let the students have a good preparation for the future. In addition, the enterprises also play a significant role in this process. If the college is the place of departure, then the enterprise is the destination. So only the enterprises know what kind of talents they need, the enterprises can provide more practical chances. So it is necessary for enterprises to strengthen the cooperation with universities and colleges. Only in this way can the colleges and universities know well about the direction of the training. Then the enterprises are the best places for the students to have the practice. So the enterprises need to provide more practical bases for the students, which can benefits both the students and the enterprises. On the one hand, the students can know their advantages and disadvantages from the practice. On the other hand, the enterprises can also know the students well, which can shorten the adaptive phase of the new employee and is helpful to the personnel recruitment. What's more, the essential part is about the talents themselves, for they are the principal part of the participation. Firstly, the students should pay attention to the study of the professional knowledge which is the basic requirement for a job. Then the talents need to pay the emphasis on the the improvement of the comprehensive abilities, and the last one is the promotion of the self-cultivation. Combined with all these aspects, the cultivation of the Business English talents can meets the need of the export-oriented enterprises. And then it can achieve the effective connection between the development of the regional economy and the cultivation of the talents.

\section{Acknowledgments}

This paper is supported by Project of Education, Science and Research of Shandong Province (No.15SC105), and Humanities and Social Science Research Projects of Shandong Province (No.J16WC49).

\section{References}

Fairclough, N. (1989). Language and Power. London: Longman.

Ferris, D. R. (2015). Second Language Writing Research and Written Corrective Feedback in SLA: Intersections and Practical Applications. Studies in Second Language Acquisition, 32, 181-201. https://doi.org/10.1017/S0272263109990490

Hutchinson, W. (1997). English for Specific Purpose: A Learning-Centered Approach. London: Cambridge University Press.

Krashen, S. D. (2010). Principles and Practice of Second Language Acquisition. Oxford/New York: Pergamon.

Robinson, P. (2000). Language for Specific Purposes. In M. Byram (Ed.), Encyclopedia of Language Teaching and Learning (pp. 337-342). London: Routledge.

Widdowson, H. G. (2008). English for Specific Purposes: Griteria for Course Design.

Yang, Y. H. (2012). The Differences of Classroom Inquiry of Different Levels in College English Graded Teaching Pattern. Foreign Language Teaching Theory and Practice, 3, 236.

Zhang, C. P. (2015). Empirical Research on Higher Vocational English Teaching under 
the Background of Multilevel Students-Take Suzhou Agricultural Vocational and Technical College as an Example. Wuxi Vocational and Technical College Journal, 6, 56.

Submit or recommend next manuscript to SCIRP and we will provide best service for you:

Accepting pre-submission inquiries through Email, Facebook, LinkedIn, Twitter, etc. A wide selection of journals (inclusive of 9 subjects, more than 200 journals)

Providing 24-hour high-quality service

User-friendly online submission system

Fair and swift peer-review system

Efficient typesetting and proofreading procedure

Display of the result of downloads and visits, as well as the number of cited articles Maximum dissemination of your research work

Submit your manuscript at: http://papersubmission.scirp.org/

Or contact ce@scirp.org 